\title{
Career Patterns of Academic Library Administrators
}

\section{Barbara B. Moran}

\begin{abstract}
A survey examined the career progression of a group of academic library administrators over a period of ten years in an attempt to identify the professional and personal characteristics associated with success in attaining a directorship in an academic library. The findings suggest that two career progression patterns have existed in academic librarianship. The first pattern, typical of males, required the acquisition of professional credentials and geographic relocations to achieve a directorship. The second pattern was typical of the females whose likeliest chance of attaining a directorship was found in internal promotions and rising through the ranks in one institution.
\end{abstract}

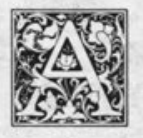

lthough librarianship is categorized as a "women's" profession and nearly 80 percent of librarians are women, the profession exhibits the same pattern of sex distribution as the male professions, that is, with females concentrated in the lower positions of the library hierarchy. Survey after survey has documented that women are far less likely than men to be appointed as library directors and there is a general awareness in the profession that females have a difficult time attaining a director's position. ${ }^{1}$ Although various conjectures have been made to explain the small number of female directors, little research exists to explain why women obtain top administrative positions in libraries so much less frequently than men.

This study focused on two categories of factors associated with success in becoming a library director. The first category was composed of professional qualifications, including items such as level of education, number of publications, activity in professional organizations, and years of administrative experience. The second category was composed of personal factors such as marital status, number of children, and ease of geographic mobility.
These two groups of variables, the professional and the personal, were chosen as the focus of this study because explanations of female underrepresentation in top administration usually advance these factors as the probable causes of the small number of female administrators. These two explanations are often found in library literature as well as in the literature of other professions. ${ }^{2}$. It was the purpose of this study to determine the relationship between these factors and attainment of a director's position.

The librarians studied were all academic librarians who had held positions as either an-assistant or an associate library director in a four-year college or university library during the academic year, 1970-71. Individuals who had held these titles were chosen as the focus of this study for several reasons. First, a brief preliminary study revealed that the position of library director was often preceded by a position as an assistant or an associate library director. Second, since the function of an assistant or associate library director is typically general administration, and often involves formulating library policy, it is reasonable to assume that incumbents of these positions are likely to try for and at-

Barbara B. Moran is assistant professor in the School of Library Science, The University of North Carolina at Chapel Hill. 
tain a director's position as a logical step in their career patterns. This research examined a group of individuals one step away from the top administrative position in an academic library, and then compared those who became directors with those who did not. Thus, the study was concerned only with individuals who had proven administrative competence demonstrated by the fact that they had all attained an assistant or associate library director's position.

\section{METHODOLOGY}

The primary method of data collection used was a questionnaire mailed to a group of librarians who, in 1970, had either been an assistant or associate library director in a four-year college or university. There were 695 such individuals listed in the 1970-71 American Library Directory. During the fall of 1980 current addresses were obtained for as many of these individuals as possible, using various library and professional association directories. Either current or tentative addresses (within the last five years) were obtained for 535 individuals. After sending out the questionnaires, it was discovered that of these 535,91 people were either deceased or had moved without any forwarding address. These individuals were excluded from further study resulting in a research population of 444 .

A review of the research on career progression in libraries produced no existing instrument which could be applied to this study, therefore, a questionnaire was constructed. Questionnaire items fell into three main categories: (1) questions concerning the progression of an individual's career in librarianship, (2) questions concerning professional qualifications, and (3) questions concerning the personal characteristics of the individual.

Career progression questions were intended to gather information about the individual's current position (or last position, if retired), the type of library where employed, number of volumes in the library, number of professional librarians employed, and the number of students served. Respondents were asked to list all full-time library positions held and the dates and institutions where they held those positions.

Questions concerning professional qualifications asked about academic degrees, the years these degrees were obtained, and undergraduate majors. Respondents were asked to list how many professional conferences they had attended in the last twelve months, and the number of professional or scholarly organizations to which they belonged and their activity with each. Finally, they were asked to list the publications they had in various writing categories.

Questions relating to personal characteristics gathered data about the respondent's age, sex, current marital status, number of children, age of children, employment of spouse, and number of geographic relocations.

There were 320 usable responses, producing a final response rate of just over 72 percent. Of the 320 respondents, 193 (60 percent) were males and 127 ( 40 percent) were females. The sexual composition of the respondents was not representative of academic librarianship, which is approximately 35 percent male and 65 percent female, but is fairly representative of academic library administration. ${ }^{3}$

The mean age of the respondents was 54.7 years with the average female (mean age, 58.5) older than the average male (mean age, 52.2). In terms of marital status there was a striking difference between the males and females in the survey. A large proportion of the females-nearly 70 percent-were unmarried at the time of the survey, and over 50 percent of the females had never been married. In contrast, over two-thirds of the males were married at the time of the survey and fewer than 20 percent of the males had never been married. The respondents to the survey, both males and females, did not have large families. Indeed, 27.2 percent of the males and 65.1 percent of the females had no children at all. Looking only at that portion of the population who reported having children, the mean number of children was 2.6 for the males and 2.4 for the females.

There was no difference in the average age at which both males and females as- 
sumed their first full-time professional library position-for both the average age was 29 . The males had become assistant or associate library directors at a younger age than the females, however. On the average, males had assumed such a position at the age of 38 , while females had become assistant or associate library directors at an average age of 42 .

The population in this study was a welleducated one, with more than 85 percent of the respondents possessing at least one master's degree, nearly 25 percent possessing a second master's or a sixth-year degree, and nearly 10 percent possessing a doctorate. A larger percentage of males held a second master's or a Ph.D., and, probably reflecting the older average age of the females in the survey, a larger percentage of females had the fifth-year bachelor's degree in librarianship as their highest degree.

In terms of professional activities, librarians in the population were frequent conference attenders and the overall pattern of conference attendance was fairly similar for males and females with the largest percentage of both reporting that they had attended five or more conferences, seminars, or workshops of at least a day's duration during the last year. The males and females were also very similar in terms of membership in professional organizations with males reporting membership in an average of 2.75 and females in an average of 2.89. In addition to looking at the number of organizations each individual belonged to, an attempt was made to gauge how active each individual was in professional organizations by having the respondents indicate the number of and types of activity they performed in each organization, for example, whether they served as officers, committee members, presented papers, or merely attended meetings. An index was constructed to categorize each individual's activity into a low, moderate, or high pattern of organizational activity. More males than females reported having a high level of activity within professional organizations while the percentage with moderate activity was about the same for each sex.

The last measure of professional qualification examined in this study was publications. Respondents to the survey were asked the number of publications they had in various categories and to list these publications. It must be emphasized that the approach used here was purely quantitative-no attempt was made to judge the quality of the publications. The responses showed a marked tendency towards greater publishing activity on the part of the males throughout all categories of publication. Although only one-third of the males reported having no publications at all, nearly 60 percent of the females reported no publications. This conforms with the pattern of fewer publications previously reported for women, not only in librarianship, but also among faculty members. $^{4}$

All respondents had been either an assistant or an associate library director during 1970 but the type of institution in which they were employed differed among the respondents, with women concentrated in college libraries, while over one-half of the men were found in research and doctoral granting institutions. Distribution of the individuals in 1970 can best be seen by classifying their institutions using the Carnegie Cassification of Institutions of Higher Education, which divides institutions according to criteria of size and type of degree offered ${ }^{*}$ (see table 1).

From this classification it is clear that the origins of the male and female assistant and associate library directors were different. The females were most commonly found as assistant or associate directors in comprehensive or liberal arts colleges while the males were more often found as assistant or associate library directors in universities.

There was also a difference in the distribution of the males and females according to whether the institutions were privately

\footnotetext{
*The subcategories used in the Carnegie Classifications (e.g., Research University 1, Research University 2 ) have not been used in the tables presented here.
} 
TABLE 1

CARNEGIE CLASSIFICATION OF EMPLOYING LIBRARY, 1970-1971

\begin{tabular}{lccccrr}
\hline \hline & \multicolumn{2}{c}{ Total } & \multicolumn{2}{c}{ Males } & \multicolumn{2}{c}{ Females } \\
\hline Research university & \multicolumn{1}{c}{$\%$} & No. & \multicolumn{1}{c}{ No. } & \multicolumn{1}{c}{$\%$} \\
Doctoral granting university & 89 & 27.8 & 75 & 38.9 & 14 & 11.0 \\
Comprehensive college or university & 38 & 11.8 & 28 & 14.1 & 10 & 7.9 \\
Liberal arts college & 98 & 30.6 & 49 & 25.4 & 49 & 38.6 \\
Professional or specialized institution & 80 & 25.0 & 31 & 16.1 & 49 & 38.6 \\
\hline
\end{tabular}

TABLE 2

PROPORTION OF DIRECTORS FROM POPULATION

\begin{tabular}{|c|c|c|c|c|c|c|}
\hline & \multicolumn{2}{|c|}{ Total } & \multicolumn{2}{|c|}{ Males } & \multicolumn{2}{|c|}{ Females } \\
\hline & No. & $\%$ & No. & $\%$ & No. & $\%$ \\
\hline $\begin{array}{l}\text { Directors } \\
\text { Nondirectors }\end{array}$ & $\begin{array}{l}107 \\
213\end{array}$ & $\begin{array}{l}33.4 \\
66.6\end{array}$ & $\begin{array}{r}71 \\
122\end{array}$ & $\begin{array}{l}36.8 \\
63.3\end{array}$ & $\begin{array}{l}36 \\
91\end{array}$ & $\begin{array}{l}28.3 \\
71.6 \\
\end{array}$ \\
\hline
\end{tabular}

or publicly supported, with females more often in private institutions (61 percent), while the males most often were employed by public institutions (again, 61 percent). Smaller institutions were measured both in terms of student enrollment (mean, 4,839 for females and 11,402 for males) and in terms of number of volumes in the library (mean, 365,000 for females and 862,070 for males).

Although this study examined the career progression of all the respondents, major emphasis was on the individuals who had become library directors in the decade between 1970 and 1980 . As table 2 shows, there were 107 members of the original research population who had become library directors. $t$

At first glance, it appears that males and females proceeded from assistant or associate directorships at roughly comparable rates; approximately 37 percent of the males became directors and 28 percent of the females. However, there were significant ways in which the male and female directors differed. The males who became directors assumed this position at an earlier age than did the females who became directors. The males became directors at an average age of 42.5 years, the females at 50.3 years. Eight ( 22.2 percent) of the females were appointed directors after the age of 61 compared with 2 ( 2.8 percent) of the males. The heaviest concentration of females as directors of libraries was in private institutions. Of the female directors, nearly 70 percent were found in private institutions while only 26.8 percent of the male directors were found in private institutions. In contrast, the males were found most frequently as library directors of public institutions. Just over 8 percent of both the male and female library directors had left the academic library field to become directors of another type of library, most commonly a public library. Four of the female directors ( 11 percent) were at the time of the survey, or had been before retirement, directors of an ARL library, 18 ( 25.3 percent) of the male directors had held such a position.

A better understanding of the locations of the directorships can be gained by placing these directorships in the Carnegie Classifications used earlier, as is done in table 3. It is clear that the female achieving a directorship was most likely to be found in a small liberal arts college; a male was more than twice as likely to be found in the research or doctoral granting university category.

One of the most surprising findings about the female directors was the high percentage who had become directors in the same library where they had previously served as assistant or associate di-

\footnotetext{
*This figure does not include that portion of the population ( $n=14$ males (7.3 percent) and 14 females (11 percent) who reported serving as an acting director but who never received a permanent appointment. It does include those who served as a library director but who have subsequently retired or moved to another position.
} 
TABLE 3

CARNEGIE CLASSIFICATION OF DIRECTORS' LIBRARIES

\begin{tabular}{|c|c|c|c|c|c|c|}
\hline & \multicolumn{2}{|c|}{ Total } & \multicolumn{2}{|c|}{ Males } & \multicolumn{2}{|c|}{ Females } \\
\hline & No. & $\%$ & No. & $\%$ & No. & $\%$ \\
\hline Research university & 18 & 16.8 & 15 & 21.2 & 3 & 8.3 \\
\hline Doctoral granting university & 15 & 14.0 & 12 & 16.9 & 3 & 8.3 \\
\hline Comprehensive college or university & 27 & 25.1 & 17 & 23.9 & 10 & 27.8 \\
\hline Liberal arts college & 28 & 26.1 & 12 & 16.9 & 16 & 44.4 \\
\hline Professional or specialized institution & 9 & 8.4 & 8 & 11.3 & 1 & 2.8 \\
\hline Nonacademic institution & 10 & 9.3 & 7 & 9.9 & 3 & 8.3 \\
\hline
\end{tabular}

rector. Of the 36 females who had become directors, only 4 became directors of libraries where they had been external candidates for the position. In addition, of this 4,3 had left the field of academic librarianship to become directors of nonacademic libraries, so only one female from the population was found as a director of an academic library where she had not previously been employed as an assistant or associate library director. The pattern ran counter to the pattern of the males as can be seen in table 4 .

\section{DETERMINANTS OF SUCCESS}

The next section of this article examines the factors distinguishing the individuals who became directors from those who did not. It will identify those personal and professional characteristics most often associated with the attainment of a director's position.

To investigate the association between the dependent variable, achieved success, and the various independent variables, multivariate cross tabulations were performed. First, the relationship between an independent variable and dependent variable was examined and then elaborated by introducing a third variable, sex. This elaboration analysis allows us to see if the original relationship between the independent variable being tested, and success in becoming a library director, still remains after controlling for sex, or if the variable affects one sex differently from the other. The chi-square $\left(X^{2}\right)$ test of statistical significance was used to determine if a systematic relationship existed between the variables.

\section{The Effect of \\ Personal Characteristics on Becoming a Director}

The relationship between each of the personal characteristics and success in attaining a directorship was examined. For the entire population there was a relationship found between marital status and becoming a director, with married individuals more likely to become directors. The chi-square for that computation was 14.88 , which is statistically significant at the .002 level, and is a strong indication that a relationship does exist between an individual's marital status and becoming a director. When the relationship was elaborated by looking at the sexes separately, the relationship remained strong for the male sector of the population. A chisquare of 11.57 was produced for this group which is statistically significant. But when the relationship between marital status and attained position in the female sector of the population was examined, the relationship between the two factors was not sustained. This indicates that for men, marriage is associated with becoming a library director. Married men have become directors in numbers disproportionate to their representation in the population. For women, however, there is no

TABLE 4

INTERNAL AND EXTERNAL SUCCESSION TO DIRECTORSHIP

\begin{tabular}{lccccrr}
\hline \hline & \multicolumn{2}{c}{ Total } & \multicolumn{2}{c}{ Males } & \multicolumn{2}{c}{ Females } \\
\hline Internal succession & No. & $\%$ & No. & No. & \multicolumn{2}{c}{ \% } \\
External succession & 53 & 49.5 & 21 & 29.6 & 88.9 \\
\hline
\end{tabular}


TABLE 5

RELATIONSHIP OF MARITAL STATUS AND RANK CONTROLLING FOR SEX

\begin{tabular}{lccr}
\hline \hline & Single & Married & $\begin{array}{r}\text { Formerly } \\
\text { Married }\end{array}$ \\
\hline Males & & & \\
$\quad$ Directors & 5 & 58 & 8 \\
$\quad$ Nondirectors & 33 & 76 & 13 \\
$X^{2}=11.57$ with 2 df & & & \\
$p<.001$ & & & \\
Females & & & \\
$\quad$ Directors & 16 & 15 & 5 \\
$\quad$ Nondirectors & 48 & 29 & 14 \\
$X^{2}=1.11$ with 2 df & & & \\
$p>.50$ & & & \\
\hline
\end{tabular}

association between marital status and attained position. The frequencies of the chi-square showing the relationship between marital status and attained position are displayed in table 5 .

The positive association between number of children and attained position was the next relationship studied. For the entire population individuals with children were more likely to be directors. When the analysis was conducted separately for males and females, however, the relationship between number of children and attaining a directorship remained statistically significant for males, but fell short of statistical significance for females as shown in table 6.

Variables associated with geographic mobility were also examined. A move of at least thirty miles was considered as a geographic move. The number of geographic moves was related to becoming a director for the entire population, but when each sex was examined separately, the relationship remained strong for males but virtually disappeared for females, as shown in table 7.
An examination of the personal characteristic variables claimed to cause fewer females to succeed in becoming directors shows that, for females, none of these variables are associated with becoming a library director. Neither a female's marital status, number of children, number of libraries worked in, nor number of geographic moves had a bearing on her success. For males, however, these variables were associated with attaining a top administrative position. A married male with children, having made a number of geographic moves and worked in a large number of libraries, was statistically more likely to become a director than an unmarried male with no children remaining in the same geographic location.

\section{The Effect of \\ Professional Characteristics on Becoming a Director}

As reported earlier, the data collected were in agreement with the results of previous studies showing that, as a whole, females scored below males on these qualifications. Females had fewer advanced degrees, fewer publications, and lower levels of activity in professional organizations. Males and females scored approximately the same in terms of number of conferences attended, and number of memberships in professional organizations.

One of the professional qualifications thought to be associated with attaining high rank in an academic library is the possession of advanced degrees. Therefore, the relationship between educational level and a directorship was the first relationship examined. For the whole population there was an association between ad-

TABLE 6

RELATIONSHIP OF NUMBER OF CHILDREN AND RANK CONTROLLING FOR SEX

\begin{tabular}{|c|c|c|c|c|c|c|c|c|}
\hline & \multicolumn{4}{|c|}{$\begin{array}{c}\text { Males } \\
\text { Number of Children }\end{array}$} & \multicolumn{4}{|c|}{$\begin{array}{c}\text { Females } \\
\text { Number of Children }\end{array}$} \\
\hline & 0 & $1-2$ & 3-4 & More & 0 & $1-2$ & $3-4$ & More \\
\hline $\begin{array}{l}\text { Directors } \\
\text { Nondirectors }\end{array}$ & \multicolumn{4}{|c|}{$\begin{array}{l}X^{2}=15.72 \text { with } 3 \text { df } \\
p<.001\end{array}$} & $\begin{array}{l}23 \\
59\end{array}$ & \multicolumn{2}{|c|}{$\begin{array}{l}X^{2}=2.15 \text { with } 3 \text { df } \\
p>.50\end{array}$} & $\begin{array}{l}1 \\
2\end{array}$ \\
\hline
\end{tabular}


TABLE 7

RELATIONSHIP OF NUMBER OF MOVES AND RANK CONTROLLING FOR SEX

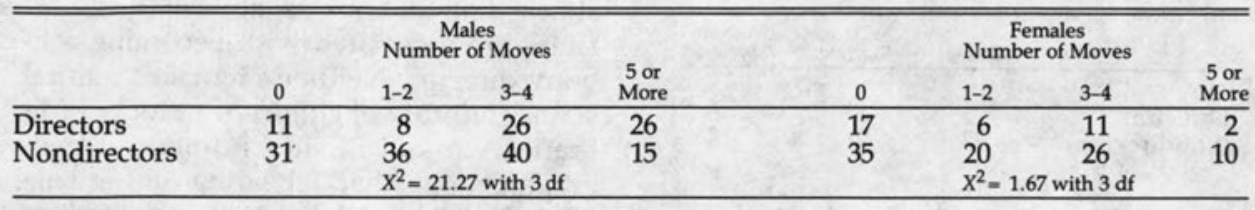

vanced degrees and directors, and the association also existed when looking at the male subsample, but a similar relationship between education and a directorship was not found for the female subsample. The relationship between these variables is shown in table 8 .

Males having higher degrees were more likely to have become directors than the females having higher degrees. For example, from the portion of the sample with Ph.D.s, 64 percent of the male doctorates became directors compared with only 25 percent of the female doctorates.

In like manner, amount of publication was strongly associated with becoming a director for the entire population. This association was maintained for the male subsample with a chi-square of 12.90 , with two degrees of freedom, which is significant at the .01 level. With the female subsample the relationship disappeared. The analysis produced a chi-square which was not statistically significant as is shown in table 9 .

The amount of organizational activity was associated with success in becoming a director for the population as a whole, and for the males. In what was becoming a familiar pattern, the relationship failed to be maintained for the females, as demonstrated in table 10.

A positive association between the number of conferences attended and being a library director was also found for the whole population, but when examined separately, the relationship held up for the males, but was not maintained for the females, as seen in table 11.

No association was found between the number of professional organizations an individual belonged to and being a library director. This relationship was the same for both males and females, as well as the total group.

Thus, it seems that professional qualifications thought to affect female career progression have little influence on which females become directors. Females with higher degrees, more publications, or greater organizational activity did not become directors more frequently than the

TABLE 8

RELATIONSHIP BETWEEN EDUCATION

AND RANK CONTROLLING FOR SEX

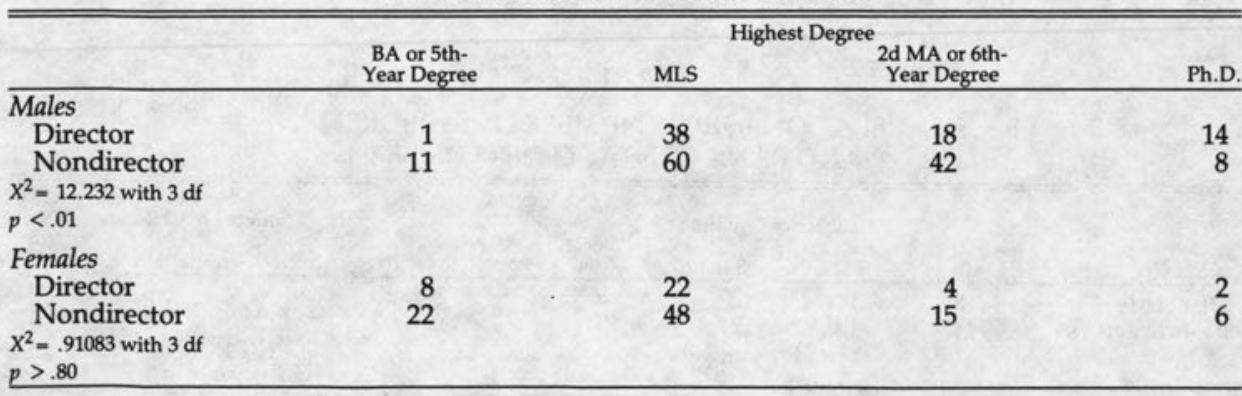


females who did not have these characteristics. For the males these external professional qualifications were clearly related to being library directors.

\section{Personal and Professional Characteristics in Different Types of Libraries}

As previously reported, women in the research population were more commonly located at smaller academic libraries and the males in larger ones. Because of this distribution it was possible that type of library (i.e., the larger research library in contrast to the smaller college library) was confounded as a variable with sex in the relationships that were found among sex, achieved success, and the various personal and professional characteristics examined in this study. For example, it could be that professional qualifications such as publishing, professional organizations, and higher academic degrees were predictors of success only for librarians in the larger research libraries, and that the observed relationships between these professional qualifications and success for males was primarily a by-product of the greater concentration of males in these larger libraries.

To provide more information on the possible confounding of sex, achieved success, and the variables studied in this research, libraries in the study were subdivided into groups based upon their Carnegie Classification.

The subjects in the study were then categorized according to the type of library in which they were last employed. For each relationship that had been observed for the population as a whole between sex, achieved success, and various personal or professional characteristics, a check was made to determine whether or not that relationship existed at each of the types of libraries. If a relationship observed for the population as a whole was also found for the librarians in each of the types of libraries, it was concluded that the relationship existed independently of the distribution of males and females across the types of libraries. The same conclusion was reached if the female directors at the

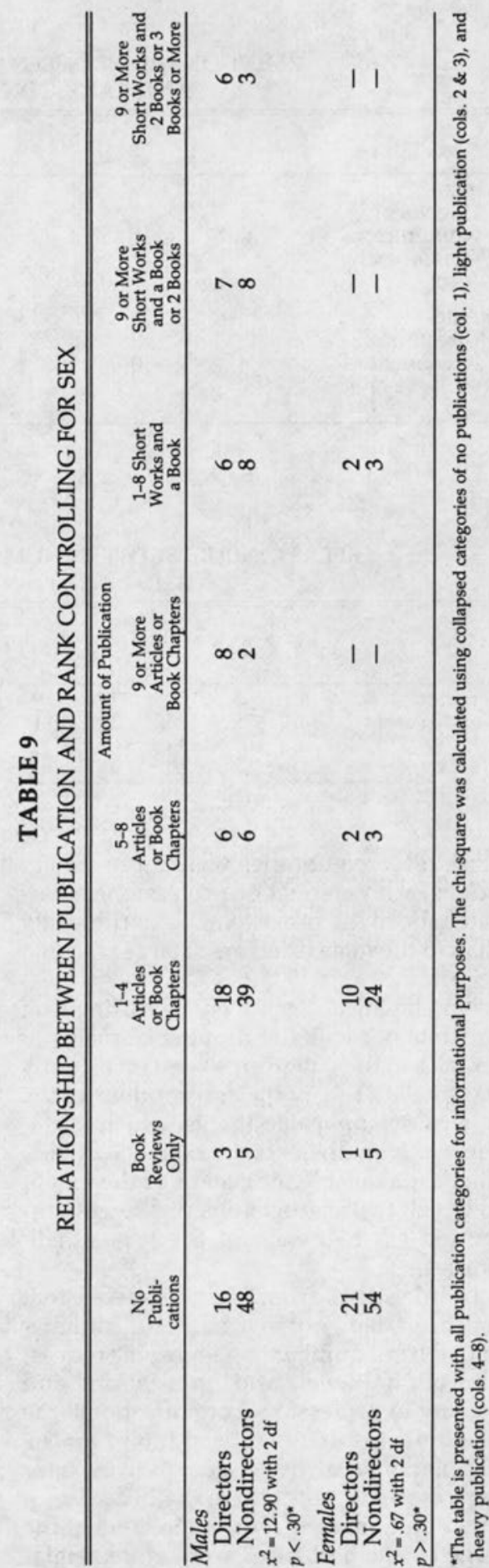


TABLE 10

RELATIONSHIP BETWEEN ORGANIZATIONAL ACTIVITY AND RANK CONTROLLING FOR SEX

\begin{tabular}{|c|c|c|c|c|}
\hline & $\begin{array}{c}\text { No } \\
\text { Memberships }\end{array}$ & $\begin{array}{c}\text { Orgar } \\
\text { Low } \\
\text { Activity }\end{array}$ & $\begin{array}{l}\text { Moderate } \\
\text { Activity }\end{array}$ & $\begin{array}{c}\text { High } \\
\text { Activity }\end{array}$ \\
\hline \multicolumn{5}{|l|}{ Males } \\
\hline & $\begin{array}{r}3 \\
18\end{array}$ & $\begin{array}{r}4 \\
17\end{array}$ & $\begin{array}{l}17 \\
45\end{array}$ & $\begin{array}{l}47 \\
40\end{array}$ \\
\hline \multicolumn{5}{|l|}{$\begin{array}{l}X^{2}=20.766 \text { with } 3 \mathrm{df} \\
p<.0001\end{array}$} \\
\hline \\
\hline Nondirectors & 10 & 28 & 30 & 22 \\
\hline $\begin{array}{l}X^{2}=2.364 \text { with } 3 \mathrm{df} \\
p>.50\end{array}$ & & & & \\
\hline
\end{tabular}

TABLE 11

RELATIONSHIP BETWEEN NUMBER OF CONFERENCES ATTENDED AND RANK CONTROLLING FOR SEX

\begin{tabular}{|c|c|c|c|c|c|c|c|c|c|c|c|c|}
\hline & \multicolumn{5}{|c|}{$\begin{array}{c}\text { Males } \\
\text { Number of Conferences }\end{array}$} & \multirow{2}{*}{$\begin{array}{l}5 \text { or } \\
\text { More }\end{array}$} & \multicolumn{5}{|c|}{$\begin{array}{c}\text { Females } \\
\text { Number of Conferences }\end{array}$} & \multirow{2}{*}{$\begin{array}{l}5 \text { or } \\
\text { More }\end{array}$} \\
\hline & 0 & 1 & 2 & 3 & 4 & & 0 & 1 & 2 & 3 & 4 & \\
\hline Director & 4 & 3 & 10 & 19 & 9 & 25 & 1 & 4 & 2 & 6 & 3 & 15 \\
\hline \multirow[t]{2}{*}{ Nondirector } & 14 & 18 & 23 & 25 & 11 & 22 & 4 & 12 & $1 \overline{5}$ & 16 & 13 & 16 \\
\hline & \multicolumn{5}{|c|}{$\begin{array}{l}X^{2}=13.327 \text { with } 5 \mathrm{df} \\
p<.02\end{array}$} & & \multicolumn{5}{|c|}{$\begin{array}{l}X^{2}=9.286 \text { with } 5 \mathrm{df} \\
p>.09\end{array}$} & \\
\hline
\end{tabular}

large research libraries were more similar on a given personal or professional characteristic to the other females in the study than to the male directors of large research libraries.

No statistical tests were performed on the data because the number of males or females in the subgroups was consistently too small to satisfy the assumptions of the otherwise applicable analyses such as chisquare. Nonetheless, the data do provide the best available indication of the extent to which the relationships previously discussed exist in each of the types of libraries.

In brief, this examination showed that for the variables of marital status, number of children, number of geographic moves, educational level, and publications and activity in professional organizations, the relationships that had been found for the population as a whole seemed to exist for each of the types of libraries. Likewise, it was noted that the female directors of the large research libraries were more similar on these six variables to the other females in the population than to the male directors of the large research libraries. Consequently, it was concluded that the previously reported relationships between sex, achieved success, and these six personal and professional characteristics were not by-products of the higher concentration of males in the large research libraries. ${ }^{5}$

\section{CAREER PROGRESSION PATTERNS FOR MALES AND FEMALES}

All of the variables examined in this study were ones that had been suggested as possible causes for the smaller number of female directors in academic libraries. From the findings of this research, there was no relationship between any of the variables and achieved success for the females. On the other hand, a large number of the variables were associated with success for males.

The elimination of these variables as factors in the career progression of females 
forces one to look elsewhere for an explanation of the varying career progressions of male and female academic librarians. On the basis of the career progressions of the population in this study, it is possible to speculate upon the existence of two separate career patterns that exist in academic librarianship-one pattern existing for the males and a separate pattern prevailing for the females.

For those males seeking to advance their careers, there seems to be a clear-cut scenario to follow, enabling them to rise to a directorship. If an aspirant accumulates the professional credentials of advanced degrees, participation in library organizations, some publishing, and makes a series of career moves to work in different academic libraries, the chances are good that the would-be director will attain such a position. But one caution based on the experiences of the males in this study-the directorship must be attained before the age of fifty, or the chances for reaching a top position are reduced considerably.

For females, again based on the experiences of the ones in this study, the male game plan would not be successful. Even if they take the time and the trouble to amass the professional qualifications that seem required of a director, they will not necessarily be rewarded for their investment. None of those qualifications were associated with being a director for females. For the females in this study, the only constant in becoming a director was to stay in the institution where they had been an assistant or associate library director. As previously noted, only one female in the study became a director of an academic library where she had not worked as the assistant or the associate director, and that seems strong evidence that for a female, the likeliest route to a directorship is to try to get an administrative appointment in the best academic institution possible and to stay put.

If this pattern of administrative success for females exists, it explains many of the discrepancies in the association between the variables and becoming director. For instance, professional credentials would not be so important a factor in the hiring of a female, who, as an internal candidate, applied for the directorship. An internal candidate's strengths and weaknesses are well known, and proven administrative competence is apt to be the deciding factor. Professional credentials are presumably weighed more heavily in the case of an unknown external candidate as a measure of suitability for the job. This pattern of female succession to the directorship would also explain why factors such as marital status seem to have no bearing on which of the females became directors, because if almost the only way a female can become a director is to stay in the same library for a good number of years, family constraints such as lack of geographic mobility would not be a factor associated with success. The older age at which females become directors (average age, 50.3 years in this study) would also help explain why there was no significant difference in attaining a directorship between women with children and childless women, since it is unlikely that few women of that age would have young children requiring extensive child care.

Metz reported that libraries hiring a director preferred to hire both an outside candidate for the job and preferred to hire a male, with his data indicating that neither women, nor inside candidates, were preferred for such positions. He also posited that there is an interaction between the variables of sex and external succession, so that a "wrong" combination of the two is especially unacceptable, that is, a female, external candidate would be the least acceptable type of individual to be hired as a director.

In his study Metz found women were three times as likely as men to have been hired to directorships from within the library. The data gathered in the present study are similar to the findings of Metz, in that 32 out of 36 females who became directors reached that position via the internal succession route while only 29 out of 71 of the males who became directors did so by internal progression.

The rate of internal succession for both males and females in Metz's study was lower than the internal succession rate of the librarians in this study, probably because of the populations studied. Metz 
studied individuals who were already directors, and their positions before assuming a directorship. It is likely that internal succession is a more common career move for someone already in an assistant or associate position.

The findings in this study corroborate the earlier work of Metz, and show that females are most likely to be hired as directors from within a library where they are already employed, and that the administrative opportunities open to women are more restricted than those open to men.

If the career patterns of the respondents to this survey are an accurate depiction of the career patterns of female library administrators, they serve as an indictment both of the hiring and promotion practices prevalent in librarianship. If a profession that is 80 percent female has such a fear and distrust of females as directors that only a female who has been a long-term success as an administrator is likely to be hired as a director, then something is seriously wrong with the perception of females as library administrators. If the pattern described above still prevails in librarianship, the ambitious woman wishing to become a director has many avenues of advancement closed to her, and has to passively await an opening in her present institution.

The problem of female underrepresentation in administrative librarianship positions remains a serious one. The 75,000 women librarians in the United States deserve to have this problem explored, and definitive explanations produced, so that remedies can be made. This study has begun to explore some of the reasons for the differential career progressions of males and females, but there are many questions that remain to be answered. The need for further research is clearly indicated and the position of women in libraries justifies the necessity for such research.

\section{REFERENCES}

1. For instance, see L. S. Estabrook and K. M. Heim "A Profile of ALA Personal Members," American Libraries 11:654-9 (Dec. 1980).

2. For use of the explanations in librarianship, see J. T. Carey, "Overdue: Taking Issue with the Issues," Wilson Library Bulletin 45:593-94 (Feb. 1971) or R. L. Simpson and I. N. Simpson, "Women and Bureaucracy in the Semi-Professions" in A. Etzioni (ed.) The Semi-Professions and Their Organizations.(New York: Free Pr., 1969). For use of the explanations in a field other than librarianship, see S. E. Esther "Women as Leaders in Public Education," Signs 1:363-81 (1975).

3. R. J. Talbot and A. Lippe, Salary Structures of Librarians in Higher Education for the Academic Year 1975-76 (Chicago: Association of College and Research Libraries, 1976).

4. P. D. Morrison, The Career of the Academic Librarian (Chicago: American Library Assn., 1969); J. A. Centra, Women, Men and the Doctorate (Princeton: Educational Testing Service, 1974).

5. B. B. Moran, "Career Progression of Male and Female Academic Library Administrators" (Ph.D. diss., State University of New York, Buffalo, 1982).

6. P. Metz, "Administrative Succession in the Academic Library," College and Research Libraries 39: 358-64 (Sept. 1978). 